\title{
HIGH TEMPERATURE BATTERY FOR DRILLING APPLICATIONS
}

\section{FINAL REPORT}

Project start date: October 1, 2006

Project End Date: December 31, 2009

Josip Caja

( Project Director )

April 30, 2010

DOE Award Number: DE-FC26-06NT42946

Electrochemical Systems, Inc.

9052 Highbridge Dr

Knoxville, TN 37922 
"This report was prepared as an account of work sponsored by an agency of the United States Government. Neither the United States Government nor any agency thereof, nor any of their employees, makes any warranty, express or implied, or assumes any legal liability or responsibility for the accuracy, completeness, or usefulness of any information, apparatus, product, or process disclosed, or represents that its use would not infringe privately owned rights. Reference herein to any specific commercial product, process or service by trade name, trademark, manufacturer, or otherwise does not necessarily constitute or imply its endorsement, recommendation, or favoring by the United States Government or any agency thereof. The views and opinions of authors expressed herein do not necessarily state or reflect those of the United States Government or any agency thereof." 


\begin{abstract}
In this project rechargeable cells based on the high temperature electrochemical system $\mathrm{Na}$ /beta"-alumina/S(IV) in $\mathrm{AlCl}_{3} / \mathrm{NaCl}$ were developed for application as an autonomous power source in oil/gas deep drilling wells. The cells operate in the temperature range from $150^{\circ} \mathrm{C}$ to $250^{\circ} \mathrm{C}$. A prototype DD size cell was designed and built based on the results of finite element analysis and vibration testing. The cell consisted of stainless steel case serving as anode compartment with cathode compartment installed in it and a seal closing the cell. Critical element in cell design and fabrication was hermetically sealing the cell. The seal had to be leak tight, thermally and vibration stable and compatible with electrode materials. Cathode compartment was built of beta"-alumina tube which served as an electrolyte, separator and cathode compartment. Beta"-alumina was bonded to alumina header and closed by an alumina top glass bonded to the alumina header. Tungsten tubing centrally located and protruding out of the alumina top was glass bonded to alumina top. It served as a filling port for the cathode and it hermetically sealed the cathode compartment by laser welding a tungsten disc. Thermo compression bond formed between alumina header and stainless steel case sealed anode compartment. All the seals were helium leak tight, however, welding the tungsten filling port was challenging. Sealing it required development of a special welding method. Leak tight welded tungsten joints were obtained and DD size cells assembled. Limited amount of data for testing the electrochemical cell performance were produced due to the short time available for testing. It seems that all seals are leak tight and compatible with electrode materials and that commercial cells can be built based on the above experience. These cells can be submitted to performance testing as well as safety testing. Upon successful completion of these tests the cells can be tested in a down-hole environment.
\end{abstract}




\section{TABLE OF CONTENTS}

SECTION

DESCRIPTION

PAGE

List of Figures

1. Executive Summary

1

2. Background 3

3. Objectives 6

4. Scope of Work 7

5. Results and Discussion $\quad 8$

5.1 Task 1 Development and Performance Testing of the 8

Prototype Seal

5.1.1 Seal Design 9

5.1.2 Cathode Compartment Seal 9

5.1.3 Anode Compartment Seal 13

5.1.4 Finite Element Modeling (FEM) 13

5.1.5 Leak Testing 16

5.2 Task 2 Development of the Prototype Rechargeable High 17

Temperature Cell

5.2.1 Design and Assembling of a Dummy Cell 17

5.2.2 Vibrations testing of the Dummy Cell 18

5.2.3 Thermo Compression Bond(TCB) 20

5.2.4 Welding of Filling Port 22

5.2.5 Prototype DD Cells 25

5.2.6 Electrical Performance of Cells 27 
TABLE OF CONTENTS(continued)

\section{SECTION}

\section{DESCRIPTION}

5.3 Task 3 Testing DD Cell in Down-hole Environment

6. Conclusion

7. References
32

PAGE

29

34 


\section{LIST OF FIGURES}

FIGURE

DESCRIPTION

PAGE

1
Schematic Diagram of Na/S(IV) Cell

Cross-section of a Cell Showing Detail for a Seal

Typical Test Cell for Compatibility Testing of Sealing

11

Glass

Finite Element Model of a Cell (Cross-section View

15

of the Cell)

Dummy Cell after Vibration Testing

Detail of the Welded Joint Tungsten-Tungsten Disk

Welded Tungsten Tube Joint

25

Assembled DD Cell

26

Cathodic Compartment; Beta"-alumina Tube Glass

26

Bonded to Alumina Header and Alumina Header

Bonded to Alumina Top

Discharge/Charge Curves for DD Cell at $200^{\circ} \mathrm{C}$

and $200 \mathrm{~mA}$

Charging Curve for DD Cell at $200^{\circ} \mathrm{C}$ and $200 \mathrm{~mA}$ 


\section{EXECUTIVE SUMMARY}

Rechargeable cells based on the electrochemical system Na/beta"-alumina/S(IV) in $\mathrm{AlCl}_{3} / \mathrm{NaCl}$ have been known for sometime and have been studied as a candidate for different applications. The operating temperature for the system is in the range of $150^{\circ} \mathrm{C}$ to $250^{\circ} \mathrm{C}$. The main goal of this project was to develop a prototype of the cell Na/beta"alumina/S(IV) in $\mathrm{AlCl}_{3} / \mathrm{NaCl}$ for application as a power source in the oil/gas deep drilling at high temperatures. Further, it is intended that upon successfully completing testing of electrochemical performance (charge/discharge cycling) and safety testing, the cell will be ready for commercial application.

A prototype DD size cell was designed and built. It comprised stainless steel case which served as anode compartment and cathode compartment installed in the stainless steel case. Both compartments were closed by a seal. Sodium is used as anode and S(IV) in $\mathrm{AlCl}_{3} / \mathrm{NaCl}$ as a cathode. Due to the nature of the electrode materials (cathode material especially) it was determined earlier that there are several materials compatible with electrode materials (cathode). One of the critical components for good operation of this cell was seal. The seals have to be leak tight, thermally stable and compatible with electrode materials. The components for building the seals were selected based on the long term compatibility studies with cathode materials at $250^{\circ} \mathrm{C}$. For example, tungsten/glass seal leaked after 305 days when exposed to $\mathrm{AlCl}_{3} / \mathrm{NaCl}$ melt at $250^{\circ} \mathrm{C}$ but alumina/glass/beta"-alumina seal during same time did not leak when exposed to S (IV) in $\mathrm{AlCl}_{3} / \mathrm{NaCl}$ and at $250^{\circ} \mathrm{C}$. The cell is equipped with several seals: cathode compartment seal, anode compartment seal, and filling port seal. The cathode compartment seal consists of the beta"-alumina tube attached to alumina header which is glass sealed to alumina top plate. Beta"-alumina tube is employed as an electrolyte, separator and cathode compartment. A tungsten tube was protruded through the alumina top and glass sealed to it served as a filling port for the cathode; it was closed by welding it. Thermo compression bond (TCB) formed between an alumina header and stainless steel case functions as the anode compartment seal. All the seals were leak tight determined by helium leak testing. The design of the prototype cell was impacted by Finite element modeling (FEM) and vibration testing of a dummy cell. FEM showed that stresses are high at room temperature which would decrease significantly with an increase in temperature. For example, it would decrease in half at $250^{\circ} \mathrm{C}$. Alumina parts are not overstressed. It is important in any seal that the ceramic material is not overstressed. Ceramic materials are generally weak, especially in tensile strength. Dummy cell tested on vibrations employed liquids similar in density to the electrodes at down-hole temperatures. These two liquids had different properties, for example, conductivity. During vibrations testing if the electrolyte brakes it will allow mixing of the two liquids. The mixture will have different properties from the original solution, for example, resistance. For one dummy cell the electrolyte broke during vibration testing. Next cell passed the test intact because changes in the cell were made based on the results obtained for the cell which did not pass the test. 
Laser welding of the tungsten filling port was the last operation in assembling the cell. Welding of tungsten is very demanding on the welding equipment, mechanical properties of tungsten and welding environment. Tungsten shows high brittle to ductile transit temperature $\left(>200^{\circ} \mathrm{C}\right)$. Its mechanical properties depend on the fabrication method. Pulse welding was used with pulses of different power profile and of different time durations. The welding of the cells was performed in a specially designed fixture which maintained pure inert atmosphere absent of traces of oxygen. A number of cells were assembled and their filling port welded with various levels of success. The very first ones showed the cracks in the welded joint and very high leak rates, whole the later ones were successfully welded and they were leak tight. The most recent cells were welded and submitted to electrical performance testing. Initial results demonstrated expected behavior, however, after testing them for some time they indicated a leak in the tube. This again was not due to the welding because welds were absent of any cracks, while the leak in the tube is due to the mechanical method of manufacturing of tubes. By using tungsten tubes made by non-mechanical means this obstacle will be removed.

The complete testing of the electrical cell performance and safety testing had to be discontinued because the project ran out of time. During this project five different types of seals had to be developed and tested. Three glass seals, TCB and the last one involving welding of tungsten filling port which was the most time consuming to develop. Therefore it took much longer time to develop it than originally anticipated. Among the challenges were the selection of Laser of proper power and pulse parameters and quality, geometry and tolerances for tungsten filling port.

Final assembly of commercial cells would be relatively simple because it would involve only a few parts and operations such as fabrication of metal case and cathode compartment then loading the electrode materials and welding anodic and cathodic compartments. Upon fabrication of the cells and based on the favorable results of the electrochemical performance testing and safety testing these cells will be ready for testing in the down-hole environment. 


\section{BACKGROUND}

Majority of the natural gas produced in the U.S. is obtained from shallow very mature reservoirs. Future gas reserves will come from deeper formations. The development of these reservoirs is limited because present day drilling systems cannot withstand the severe conditions( high temperature, high pressure, highly corrosive gases) existing in that environment. New drilling systems ought to be developed in order to exploit future deeper and hotter reservoirs.

In order to meet future national gas demands DOE has initiated several programs to develop new high temperature, high pressure drilling technologies which will operate in very deep $(>20,000$ feet $)$, high temperature $\left(>200^{\circ} \mathrm{C}\right)$, high pressure hard rock corrosive environments.

Logging While Drilling (LWD) and Measuring While Drilling (MWD) tools are powered by an autonomous power source which most often, is a battery. Present tools operate at temperatures below $150^{\circ} \mathrm{C}$ mainly because the components including the battery cannot operate at higher temperature. Drilling and logging services need hightemperature batteries that increase the temperature limits, as well as the improvement of battery safety.

Geothermal and deep petroleum fields, such as those in Texas, the Rockies, and the Gulf of Mexico, necessitate high-temperature drilling systems that can reliably operate at $150^{\circ} \mathrm{C}-230^{\circ} \mathrm{C}$ and can survive to $250^{\circ} \mathrm{C}^{1}$. The complexity of these formations necessitates high-temperature battery power to enable MWD operation. The majority of new deep wells are highly deviated ${ }^{2}$, and these cells should provide power in the deviated wells where conventional wireline logging is difficult. 
The highest temperature oilfield/gas-compatible lithium-based chemistry is the lithium-magnesium/ thionyl chloride battery, which was developed as a result of a Halliburton -DOE-Battery Engineering collaboration. Safe use of this chemistry has been limited to $200^{\circ} \mathrm{C}$ and there do not seem to be good prospects for increasing the operating temperature or for increasing the safety of the cells. Polymer-based chemistries were considered but then rejected because they tend to fail when soaked at high temperature. These lithium based batteries are primary batteries. Rechargeable cells are preferable over primary cells because they offer more jobs per cell, which lowers life cycle costs, reduces environmental disposal, and opens new applications.

This project offered the use of sodium-sulfur (IV) batteries to address the needs for high-temperature batteries in geothermal, gas and deep petroleum wells. Sodiumsulfur (IV) battery is a rechargeable battery with high energy density, high power density, high voltage, high cycle life, no self discharge, and operation from $150^{\circ} \mathrm{C}$ to $250^{\circ} \mathrm{C}^{3}$. The key battery parameters are given in

\section{Table 1.}

\section{Table 1: Summary of expected battery performance}

Energy density: $\quad 400 \mathrm{Wh} / \mathrm{L}$ and $140 \mathrm{Wh} / \mathrm{kg}$

Open circuit voltage (OCV): $4.25 \mathrm{~V}$

Operating temperature: $105^{\circ} \mathrm{C}$ to $250^{\circ} \mathrm{C}$

Peak performance: $150^{\circ} \mathrm{C}$ to $240^{\circ} \mathrm{C}$

Charging rates: $\quad 0.1 \mathrm{C}$ to $0.5 \mathrm{C}$

Cycle life: $>1,000$ cycles at $100 \%$ depth of discharge

Self discharge: none

Internal Resistance: $\quad 0.2-1.0 \Omega$ at $230^{\circ} \mathrm{C}$

Target size: DD

Sodium-sulfur (IV) batteries consist of an enclosure containing a sodium anode 
separated from the cathode by a beta"-alumina tube, which contains the cathode composed of sodium chloride -aluminum chloride melt and sulfur. The beta"-alumina tube serves as electrolyte, separator and cathode compartment. The cell compartments are closed by a seal.

The initial chemistry development and laboratory cell tests were performed at the University of Tennessee (Dr. G. Mamantov's lab) and were funded by a DOE Basic Chemistry and Basic Sciences grant, contract number EY-76-S-05-5053 and DOE, University of California Subcontract 4502810 . Development of the practical sodiumsulfur(IV) cell continued over 17 years by the investigators at Electrochemical Systems, Inc. (ESI) and received funding from the Air Force Aeronautical Systems Division, Wright-Patterson AFB, through a phase I and a phase II SBIR, contracts number F3361587-C-2805 and F33615-88-C-2912. The current state of development of electrochemistry and cell design reflects technical progress funded internally by ESI and by SANDIA National Laboratories, Albuquerque, NM contract No. 443157. SANDIA's funded project had three phases to develop a high temperature battery for drilling; however, due to the lack of funds only Phase I was completed.

During this development period, the practical cells went through several generations of seals. Initial generations used a mechanical type of seal while later generations used welded seals with either brazed seals or glass-to-metal seals. However, all of them employed at least one component which was not compatible with the cathode except for laboratory cells which were built form compatible materials. A cross-section schematic of a DD cell is shown in Figure 1. 
A series of cells were successfully cycled at different temperatures up to $250^{\circ} \mathrm{C}$ and at a wide range of currents. Cycle lifetime depended on the electrochemical compatibility between the materials and the components in the cathodic mix. Consequently, long cycle life requires that the seals must be built from materials that are compatible with the cathodic mix, such as glass, $\alpha$-alumina, and tungsten.

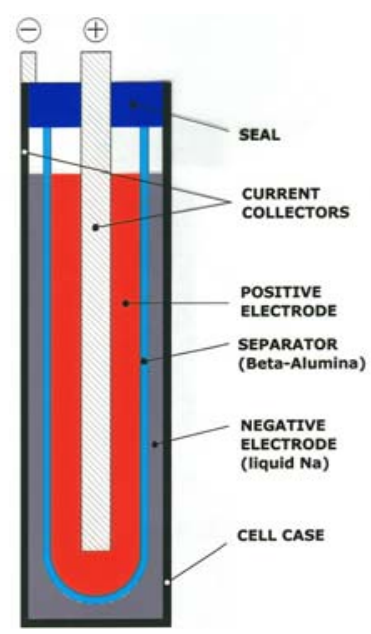

Fig. 1 Schematic diagram of $\mathrm{Na} / \mathrm{S}(\mathrm{IV})$ cell

\section{OBJECTIVES}

The objectives of this project are:

1) Develop prototype of high temperature battery to power electronics which operates in drilling and logging systems in hot wells $\left.\left(>200{ }^{\circ} \mathrm{C}\right), 2\right)$ Develop critical cell components which will be robust enough to sustain vibrations in down-hole environment, 3) Build commercially ready cells for application in high temperature drilling, 4) Test the cells in a down-hole environment.

The electrochemistry of the sodium-sulfur (IV) cell has been demonstrated, but much work remained on the packaging of the battery ${ }^{4}$. Molten salts in the cathode can 
attack the seal, especially when the cells are fully charged at high-temperature. This is the key task for this project. Materials have been identified which are compatible with the melt. The ceramic electrolyte can crack during drilling vibrations. If needed the electrolyte design for drilling vibrations can be improved to withstand drilling vibrations using experience of ESI and its subcontractor.

Stress from thermal cycling can cause fractures in the ceramic electrolyte. Our preliminary battery tests have demonstrated multiple freeze-thaw cycles on the electrolyte without any fractures.

\section{SCOPE OF WORK}

The work was divided in four principal tasks as described below.

The work comprised development of a seal compatible with the cathode mix and employing Finite Element Modeling ( FEM )to evaluate the seal design. Test of the seal performance during vibrations was tested by building a dummy cell. A DD size cell was constructed incorporating the final seal. Electrical performance of the cells was tested. The final prototype cell demonstrated to be capable of being recharged. Last task which included safety, operational, and down-hole tests on the final cells was not completed.

\section{Task 1 Development and Performance Testing of the Prototype Seal}

Task 1 included seal design for DD cell, selection of materials, compatibility testing of materials for the seal, final element modeling (FEM) of a seal, seal assembly and testing 
for leakage. FEM indicated the distribution and integrity of stresses and their consequence on the integrity of the seal.

\section{Task 2 Development of the Prototype Rechargeable High Temperature Cell}

Task 2 included dummy cell design, building subassemblies and dummy cell, vibrations testing of the dummy cell, design and building of DD prototype cell, testing electrical performance of DD cell.

\section{Task 3 Testing of DD cell in down-hole environment}

This task encompassed assembly of DD cell for commercial applications, safety testing and electrical performance testing.

It also included testing cells in down-hole environment.

\section{Task 4 Final report}

\section{RESULTS AND DISCUSSION}

\subsection{TASK 1 Development and Performance testing of the Prototype Seal}

The first task in development of the prototype of high temperature battery for drilling application was to develop the seal. The seal is a very important part of any battery. It closes the battery and protects active components (electrodes, electrolyte) from the influence of the environment and it contains the active materials within the battery. The seal is a very critical part for the high temperature battery developed in this project. It is important that the battery seal besides being leak tight, is also compatible with electrode material. Further, the seal should withstand vibrations present during drilling 
operations. In addition, it should offer safety during cell failure. This is especially important for the cathode environment (positive electrode). In the past years, ESI employed several generations of seals and their performance tested in the cells. First one was a glass seal employed in glass laboratory cells followed by mechanical compression seals and brazed seals employed in metal body cells. Of the above mentioned seals, the

best performance was achieved with the glass seal employed in glass laboratory cells ${ }^{5}$. This seal was built of materials compatible with the catholyte and cells employing this seal demonstrated very long cycle life (>1000 charge/discharge cycles). Mechanical seals and the brazed seals made of partially compatible materials were affected by the electrode materials (catholyte- $\left.\mathrm{AlCl}_{3} / \mathrm{NaCl}+\mathrm{S}\right)^{6}$. Previously built cells demonstrated that the cathode materials react with many standard construction materials (stainless steel, Kovar, nickel, aluminum) which are used for construction of the seal for cathode compartment. Anode compartment is much easier to seal due to the availability of a wide selection of compatible construction materials (stainless steel, alumina, aluminum, and others).

\subsubsection{Seal design}

Seal for the cell is composed of cathode compartment seal and anode compartment seal.

Figure 2 gives cross-section of a seal for the cell. 


\subsubsection{Cathode compartment seal}

The seal assembly comprised alumina top plate glass sealed to alumina header which is also glass sealed to the beta"-alumina tube thus closing the cathode compartment. Tungsten tube was protruded through the alumina top and glass sealed (glazed) to it serving as a filling port for the cathode. This seal made with compatible materials should make possible cell operation over a long time. For a good seal it is critical to select a type of glass which will be thermally stable in the operational temperature range( in our case up to $300^{\circ} \mathrm{C}$ ) which will have coefficient of thermal expansion very close to that of the ceramic material and very importantly which will also be compatible with cathode materials.

Alkaliboroalumosilicate glasses (Pyrex type) were employed for this application which closely matched the thermal expansion coefficient of materials used for construction of seals. Based on some previous results and preliminary tests from a number of sealing glasses two types of glasses were selected, one type for alumina/alumina seal and another for alumina/tungsten seal. One of the glasses was specially prepared while another was commercially available. 


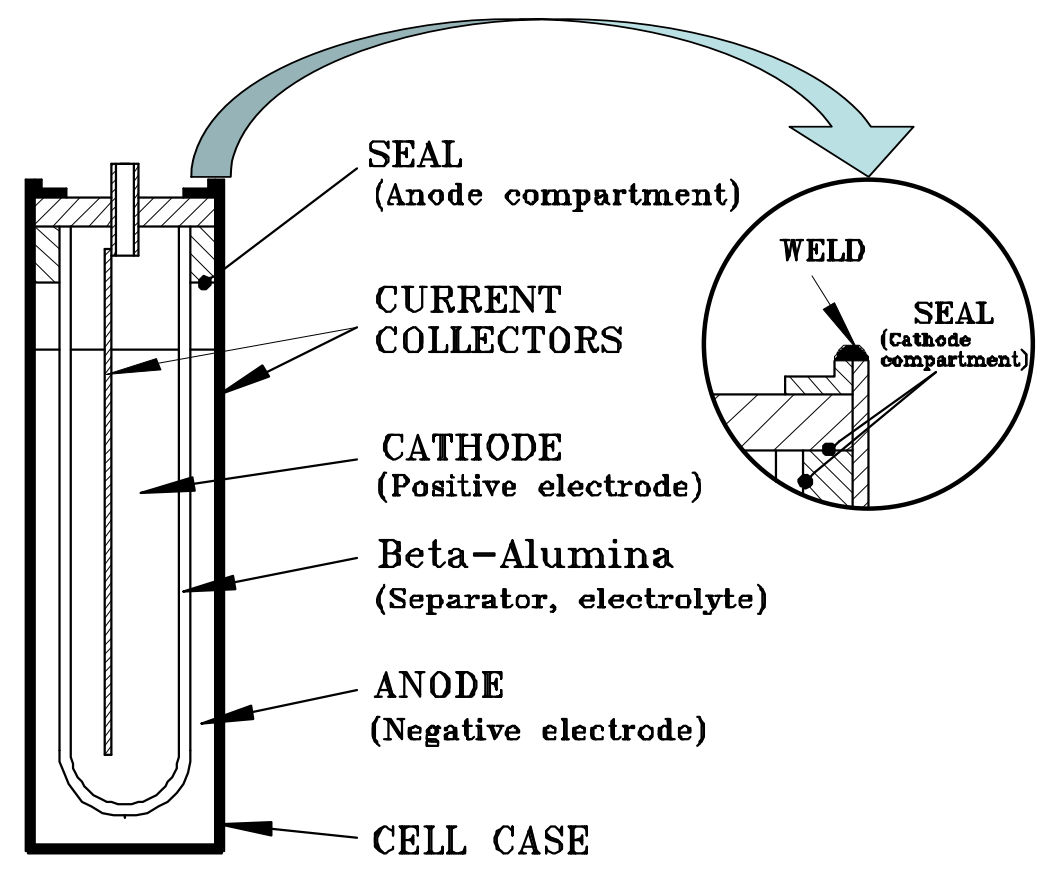

Figure 2. Cross-section of a cell showing detail for a seal

Several of these seals were made separately for testing and their compatibility tested with cathode materials.

\section{Seal-tungsten/glass}

Several seals were made by constructing cells from Pyrex glass with a tungstenglass seal on each cell. Next the melt was added to each cell, evacuated and sealed. Figure 3 presents glass cell for compatibility testing. 


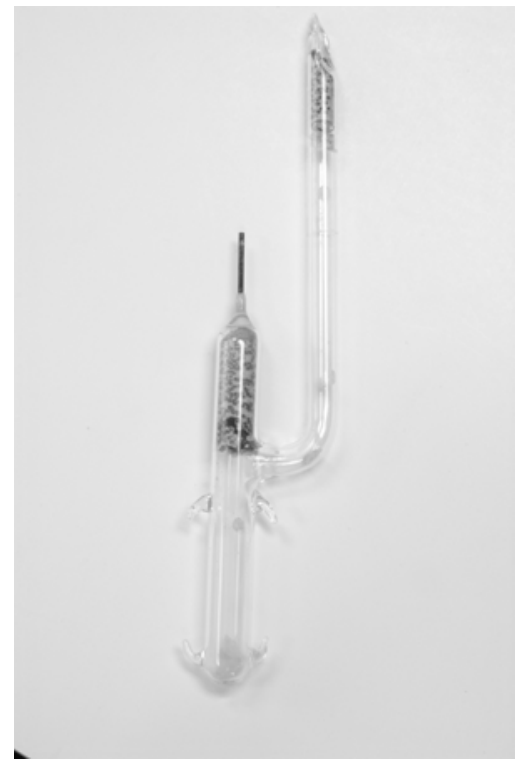

Figure 3. Typical test cell for compatibility testing Fof sealing glasses

Most of these seals were made in house except some tungsten/glass seals which were made by FUSITE, Cincinnati, Ohio.

Compatibility of sealing glasses (seals) with cathode materials was tested by exposing them to cathode materials, their composition corresponding to that of the fully charged cell, at $250^{\circ} \mathrm{C}$ for more than one month.

Results of compatibility studies of tungsten/glass seals in catholyte absent of sulfur are given in Table 2 .

Results in Table 2 indicate that seals employing oxidized tungsten surface have longer lifetime. It also appears that seals immersed in the melt are affected more by the melt. Preoxidized tungsten surface prolongs the seal lifetime when exposed to vapors only. 


\section{TABLE 2}

Duration of exposure of tungsten/glass seals to the catholyte (no sulfur) in order to observe the leak

\begin{tabular}{cccc}
\hline \multicolumn{3}{c}{ Time(days) } \\
\hline Seal exposed to vapors & Leak & Seal immersed in catholyte & Leak \\
\hline $55^{(1)}$ & yes & 67 & yes \\
$305^{(2)}$ & yes & 69 & yes \\
\hline
\end{tabular}

(1) standard tungsten, (2) tungsten surface oxidized prior to forming the seal.

One of the seals was subjected to thermal cycling between room temperature and $250^{\circ} \mathrm{C}$ to simulate temperature variations experienced from one drilling operation to another. Each thermal cycle consisted of (i) heat from $25^{\circ} \mathrm{C}$ to $250^{\circ} \mathrm{C}$ at $2^{\circ} \mathrm{C} / \mathrm{min}$, (ii) isothermal at $250^{\circ} \mathrm{C}$ for $10 \mathrm{~h}$, (iii) cool from $250^{\circ} \mathrm{C}$ to $25^{\circ} \mathrm{C}$ at $2^{\circ} \mathrm{C} / \mathrm{min}$, and (iv) isothermal at $25^{\circ} \mathrm{C}$ for $10 \mathrm{~h}$. The cell was placed in an inverted position so that the molten salt is in contact with the tungsten-glass seal. After 10 thermal cycles no leaks were observed in the seal.

However, major effect on lifetime of the seals (cells) is due to the wide temperature changes thus submitting the seals to stresses which can cause the leaks.

\section{Seal- alumina/glass/beta"-alumina}

Alumina/glass/ beta"-alumina seals were tested by introducing three samples of this seal into a compatibility glass tube together with the cathode material (catholyte$\left.\mathrm{AlCl}_{3} / \mathrm{NaCl}+\mathrm{S}(\mathrm{IV})\right)$ then evacuated and sealed. 
This seal (three samples) even after 305 days exposure to the catholyte did not indicate a leak. If catholyte (cathode mixture) changed the color or if solid precipitated in molten salt that would indicate the leak or if the two alumina materials would separate. Further testing of the catholyte (chemical analysis) as well as seals would allow determining cause for the leak. This test is very severe because the seal is exposed to the catholyte on all sides, as a consequence, the seal will be affected by the catholyte much faster. However, in practice only one side of the seal is exposed to the environment in cathode compartment.

\subsubsection{Anode compartment seal}

The anode compartment was sealed by a thermo-compression bond (TCB). It consisted of an aluminum gasket installed between alumina header and stainless steel collar. Stainless steel collar was welded to the end of the stainless steel case thus closing the anodic compartment. The alumina header was a part of both anodic and cathodic compartment seal. TCB was developed and performed in house.

\subsubsection{Finite Element Modeling (FEM)}

The designed seal was submitted to FEM (Finite Element Modeling) in order to evaluate thermal stresses that result from the manufacturing process. FEM was performed by Starboard Innovations, Houston, TX.

Figure 4 presents cross-section for Finite Element Model of the cell.

The model includes all components and materials used in the cell excluding positive current collector. Components are color coded as follows: dark blue color and 
grey color present electrode materials ( anode and cathode), narrow green region presents tungsten tubing, wider green region presents alumina header, dark red represents the glass seal, pink is for alumina top, light blue between electrode materials presents beta-alumina tube, brown color is for aluminum gasket, yellow presents stainless steel collar, and very light blue stainless steel case. Between alumina top and alumina header, and between alumina header and beta-alumina tube are two thin glass seals.

Room temperature is the most critical temperature. All stresses obtained at this temperature are very high. Here are some values calculated for the stresses; $145 \mathrm{MPa}$ compression in alumina header and in beta"-alumina tube, $250 \mathrm{MPa}$ compression in glass seal of tungsten/glass seal, 300MPa tension in steel case. Stress on the alumina top seal to tungsten is high. Yielding in metal parts will relieve some of the stresses. Alumina parts are not overstressed. Ceramic materials are generally weak, particularly in tensile strength, and it is important in any seal that the ceramic material is not overstressed. Excessive compressive stress for top glass seal was estimated. Excessive compressive stress for top assembly thin glass seals was estimated (alumina top/alumina header seal, and alumina header/beta"- alumina tube). The alumina and beta"-alumina have similar coefficients of thermal expansion therefore alumina can be bonded securely to beta"alumina with a glass seal. 


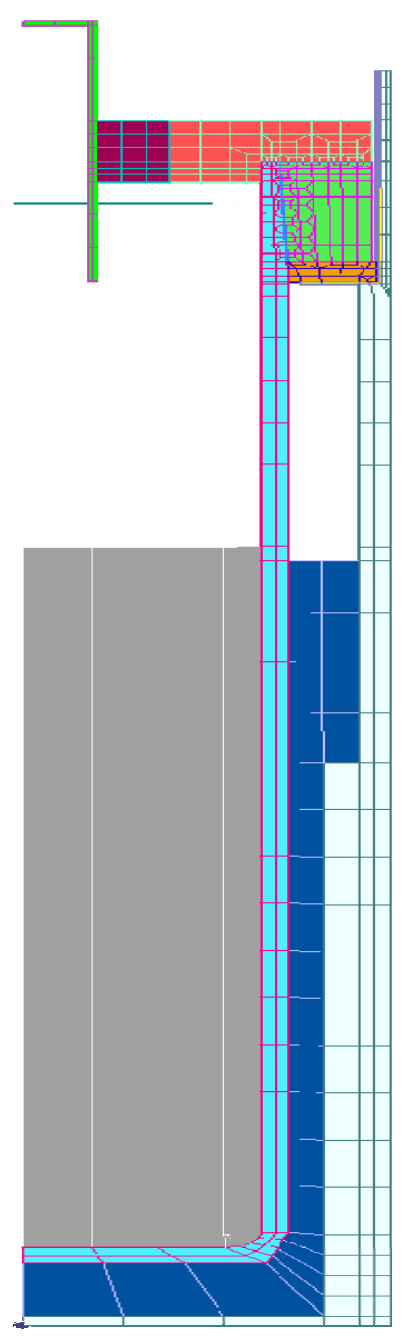

Figure 4. Finite Element Model of a cell (cross-section view of the cell)

Stresses will be relieved as temperature is increased. If batteries always operate at elevated temperature that will improve margins. At $250^{\circ} \mathrm{C}$, the stresses should be roughly half of the room temperature levels. Results estimated depend on accurate material properties, tolerances on mating parts during manufacturing, and accurate seal geometry. Based on the above analysis the geometry of the seal alumina top/glass/alumina header was modified to release compressive stresses. 
To improve confidence in the result, the model assumptions have to be validated: 1) precision measurement of geometry of glass seals, etc., 2) precision manufacturing header can be modified so as to improve compressive stresses.

However, obtained results can serve to indicate importance of parts and their geometry on total assembly as well as qualitatively show the weakest point in the entire cell structure. Obviously glass to tungsten tubing seal showed the highest compressive stress compared to the rest of the seals in the battery. This was anticipated because tungsten tubing has to be in compression in order to have a leak tight cathodic compartment.

\subsubsection{Leak testing}

A number of cathode compartment seal assemblies and single seals were built and tested for leaks. Examples of single seals are: 1) alumina top/glass/alumina header seal, 2) alumina header/glass/beta"-alumina tube seal, tungsten rod/glass/alumina seal. The assemblies are: 1) alumina top/glass/alumina header seal where alumina header was also glass bonded to beta"-alumina tube, 2) the assembly in 1) having in addition tungsten tubing centrally protruding out of alumina top and glass bonded to the alumina top, thus forming the top of the cathodic compartment.

Another cathodic compartment was built which had 1/4" diameter tungsten rod attached to the alumina top instead of tungsten tubing thus closing the cathodic compartment. This assembly was built as a trial sample, for leak testing, allowing leak testing of all single seals as well as complete cathodic compartment. 
All these seals were submitted to helium leak testing and indicated that they are leak tight (1.r. $\left.<10^{-8} \mathrm{~cm}^{3} / \mathrm{sec}\right)$. Leak detector ALCATEL model ASM sensitivity $2 \times 10^{-11}$ $\mathrm{cm}^{3} / \mathrm{sec}$ was used for leak testing. All top assemblies (alumina top/glass/tungsten tubing (rod)) were built by FUSITE. Alumina tops, and alumina headers were made by COORSTEK, Oak Ridge, TN. Tungsten tubing was supplied by Goodfellow, Oakdale, PA and Ed Fagan, Franklin Lakes, NJ. Beta"-alumina tubes were supplied by Beta Research \& Development Ltd., Needwood, UK.

Glass bondings alumina header to beta"-alumina tube as well as alumina header to alumina top were made by ESI.

\subsection{Task 2 Development of the Prototype Rechargeable High Temperature Cell}

\subsubsection{Design and assembling of a dummy cell}

The DD size dummy cell consists of stainless steel case serving as anodic compartment with beta"-alumina tube installed in it. Beta"-alumina tube bonded to alumina header served as an electrolyte, separator and cathodic compartment. Dimensions of the beta"-alumina tube were $2.3 \mathrm{~cm}$ OD (0.906 inches) and length $11.0 \mathrm{~cm}$ (4.33 inches). Alumina header insulated both compartments. Cathodic compartment was closed by a seal consisting of alumina top glass bonded to alumina header. Tungsten tubing centrally located and protruding alumina top which was also glass bonded to alumina top formed filling port for the cathodic compartment. Tungsten tubing was sealed by an elastomer thus sealing the cathodic compartment. Tungsten wire served as positive current collector. Stainless steel collar was placed between the header and alumina header and had aluminum gasket installed between them thus forming Thermo 
Compression Bond (TCB). The top end of the collar was welded to the case thus sealing the anodic compartment.

Dummy cell was built and tested on leak. It was found to be free of any leaks. Dimensions of DD cell were: outer diameter $3.18 \mathrm{~cm}(1.25$ inches $)$ and length $12.7 \mathrm{~cm}(5$ inches). The cell contained liquids similar in density to the electrodes at down-hole temperatures.

$(\mathrm{Bu})_{4} \mathrm{NBr}$ in $\mathrm{CCl}_{4}$ introduced in the beta"-alumina tube simulated catholyte $\mathrm{NaCl} / \mathrm{AlCl}_{3}+\mathrm{S}$. Density of $\mathrm{NaCl} / \mathrm{AlCl}_{3}$ in temperature range of $150^{\circ} \mathrm{C}$ to $250^{\circ} \mathrm{C}$ has value of 1.72 to $1.61 \mathrm{~g} / \mathrm{cm}^{3}$ while $\mathrm{CCl}_{4}$ has density $1.59 \mathrm{~g} / \mathrm{cm}^{3}$ at room temperature. $(\mathrm{Bu})_{4} \mathrm{NBF}_{4}$ in Diethylene glycol dimethyl ether (diglyme) simulating sodium was introduced in the stainless steel case. Diglyme has density of $0.94 \mathrm{~g} / \mathrm{cm}^{3}$ at room temperature. Density of sodium in the temperature range of $150^{\circ} \mathrm{C}$ to $250^{\circ} \mathrm{C}$ has value of 0.915 to $0.891 \mathrm{~g} / \mathrm{cm}^{3}$.

During vibrations or shock testing if the electrolyte (beta"-alumina tube) brakes it will allow mixing of the two liquids. The mixture will have very different properties from the original solutions. This change in properties will be employed for determination of the effect of vibrations on the cell integrity. For example, measuring the resistance of the cell, in the case of breakage of the beta"-alumina tube, there will be change in the resistance compared to status prior to the test.

\subsubsection{Vibrations testing of the dummy cell}

The assembled cells were submitted to vibration testing performed by Global Testing Laboratory in Knoxville, TN. 
The test comprised linear increase in frequency from $20 \mathrm{~Hz}$ to $500 \mathrm{~Hz}$ for each axis $(\mathrm{x}, \mathrm{y}, \mathrm{z})$ at $10 \mathrm{G}$ during 15 minutes. The cell completed successfully the test for $\mathrm{z}$-axis and almost completed test for $\mathrm{x}$-axis(13 minutes) before it failed. A change in resistance was measured indicating breakage of the electrolyte. When the cell was dissected it was observed that the beta"-alumina tube broke at the header and also alumina header broke in half.

The dummy cell after vibration testing (Figure 5) shows broken header and beta"alumina tube.

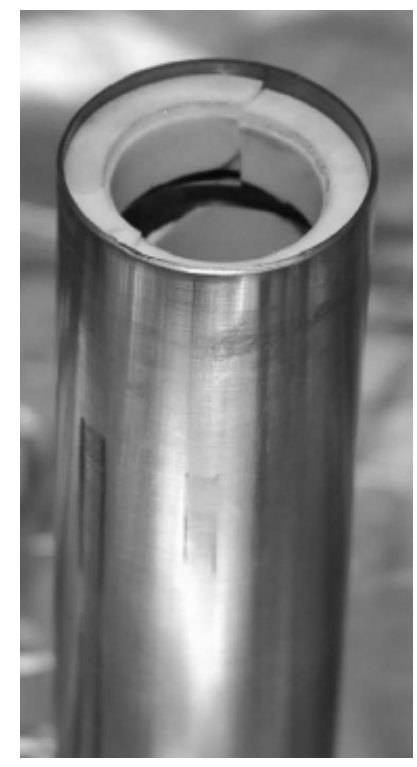

Figure 5. Dummy cell after vibration testing

Another cell was assembled and submitted to vibration test. The cell was submitted to linear vibrations from $20 \mathrm{~Hz}$ to $500 \mathrm{~Hz}$ at $10 \mathrm{G}$ during 15 minutes for $\mathrm{x}$-axis and y-axis. In addition, the cell was tested on shocks of $20 \mathrm{G}$-three shocks during $11 \mathrm{~ms}$ for each axis $(\mathrm{x}, \mathrm{y}, \mathrm{z})$. Cell resistance measured after test for each axis and shocks did not 
change demonstrating that the cell was not affected by vibrations. After completion of the testing the cell was dissected and visually inspected. There were no changes observed either in beta"-alumina tube or in the top part of the assembly. The beta"alumina tube was intact and it did not show any signs of cracks. Some changes in design were made for this cell. This cell had alumina top glass sealed to the alumina header/beta"-alumina tube assembly employing the glass preform. In addition, a metal ring was placed on the alumina top and welded to the case thus firmly holding all components together. It appears that the changes introduced into the second dummy cell resulted in a much stronger cell not affected by vibrations and shocks.

Vibration testing showed that the design of the dummy cell can be used for the prototype cells.

\subsubsection{Thermo-compression bond (TCB)}

High integrity ceramic-metal joints are required for sealing anodic compartment. The thermo-compression bond adopted is a diffusion bonded joint between alumina and stainless steel with aluminum interlayer. Pressure and high temperature are used to bring ceramic and metal members into intimate contact that produces an interfacial adhesion. Various metals and alloys have been diffusion bonded to ceramics but practical difficulties could appear due to the components. For example, the metal need to be deformed and stressing joints by thermal contraction mismatch the stresses as the bond cools. Inserting a soft material between the ceramic and metal can solve some of the problems. However, optimum fabrication conditions should be determined since the effects may differ for the ceramic-metal and metal-metal interface. This is especially 
important if brittle intermetallic compounds are formed at the metal intermediate layer interface.

The fabrication parameters (pressure, temperature, time) had to be determined and strictly controlled. Increasing the temperature caused bonds to be stronger, while those made at lower temperature failed at alumina-aluminum interface, and those formed at higher temperature $\left(625^{\circ} \mathrm{C}\right)$ failed at steel-aluminum interface due to the thick intermetallic layer. Thickness of the intermetallic layers formed at steel-aluminum interfaces increased with fabrication time. At lower pressure failures occurred at aluminaaluminum interface, however, increasing the applied pressure strengthened the aluminaaluminum interface, while failures occurred at steel -aluminum interface.

Thickness of aluminum has an effect on the strength of the TCB. An increase in thickness of aluminum made the TCB stronger and failures occurred at steel-aluminum interfaces. Fabrication was performed in an inert atmosphere (argon), or vacuum or mixture of $\mathrm{N}_{2}-\mathrm{H}_{2}$.

In order to determine parameters for fabrication of TCB for the cell a number of separate TCB seals was built and tested. The design and seal components were identical to the ones proposed for the cell. However, stainless steel case and beta"-alumina tube were not included. A stainless steel cup was used instead of the stainless steel case and beta"-alumina tube. The seal was constructed by placing a stainless steel collar in the cup, then aluminum gasket followed by an assembly consisting of alumina top glass bonded to alumina header was placed on the aluminum gasket. This testing assembly was employed to define parameters for fabrication of the TCB for the cell. 
The TCB to be built was placed in a specially made jig. Upon loading the TCB components in the jig the entire unit was evacuated then filled up with hydrogen-nitrogen mixture. The unit was slowly heated to predetermined temperature while under pressure and held at temperature for some time then slowly cooled to room temperature. Temperature, pressure, and time were varied for various thicknesses of aluminum gasket. Thickness of the gasket was very important, thin aluminum gasket would adhere to alumina but it would not bond to the steel. Thicker gaskets would bond to both alumina and stainless steel but would still leak. It appears that width of the gasket was also important for producing a good bond. Thicker gasket under pressure would squeeze some material from the TCB thus causing dimensional changes in the parts (collar) which would make it difficult to remove the assembly from the jig. After many tests and variations in parameters it was determined that the best conditions for producing a leak tight TCB are temperature between $590^{\circ} \mathrm{C}$ to $600^{\circ} \mathrm{C}$, at about 6,600 psi for 30 minutes, using an aluminum 1100 gasket 0.010 inch thick.

\subsubsection{Welding of filling port}

Last operation in assembly of the cell was welding tungsten tube and tungsten disk which served as a filling port for cathodic compartment.

High brittle to ductile transit temperature $\left(>200^{\circ} \mathrm{C}\right)$ of tungsten greatly limited its fabrication and application. Mechanical properties for tungsten depend on the fabrication method including previous history. Welding of tungsten must be carried out under controlled atmosphere, preferably, in a dry box, since any contamination by oxygen will 
reduce the ductility of the joint. Tungsten can be welded by TIG welding, laser beam welding, plasma welding, friction welding, and electron beam welding.

Electron Beam Welding and Laser Beam Welding were used for welding the filling port of $\mathrm{Na} / \mathrm{S}(\mathrm{IV})$ cell.

For this cell assembly a specific welding method was developed by step by step approach. First, parameters for welding of tungsten tubing and tungsten disk were determined and next the parameters for their welding as part of the alumina top, and, finally, for welding tungsten tubing and tungsten disk in an assembled cell.

A number of attempts were made to weld the filling port using Electron beam welding method. However, these attempts were unsuccessful. Welding of tungsten parts resulted in their cracking. Some of the welds made were partially successful, but it was observed that the tungsten disk had developed a very thin crack. Further work using this method was discontinued because improvement of the welding process required some changes in the equipment used. Electron Beam Welding was performed by BrushWellman Electrofusion Products, Fremont, CA.

First Laser welding attempts were also unsuccessful. Welding tungsten tubing to a disk was carried out in specially built fixtures filled up with an inert gas(argon or helium) to eliminate impurities(oxygen). Only after several different types of Laser welding equipment were tried and several changes made in the welding fixture as well as in the method of supplying the inert gas, good leak tight tungsten welded joints were obtained. To get successful welds, pulse welding was applied. This method allowed welding parameters to be varied, for example, pulse width, pulse energy, pulse shaping, and repetition rate. 
Initial results showed a substantial cracking in the weld area indicating that the design of the joint is very critical and must be designed so that the material is not constrained and have freedom to shrink upon solidification.

Figure 6 presents welded joint tungsten tube/tungsten disk.
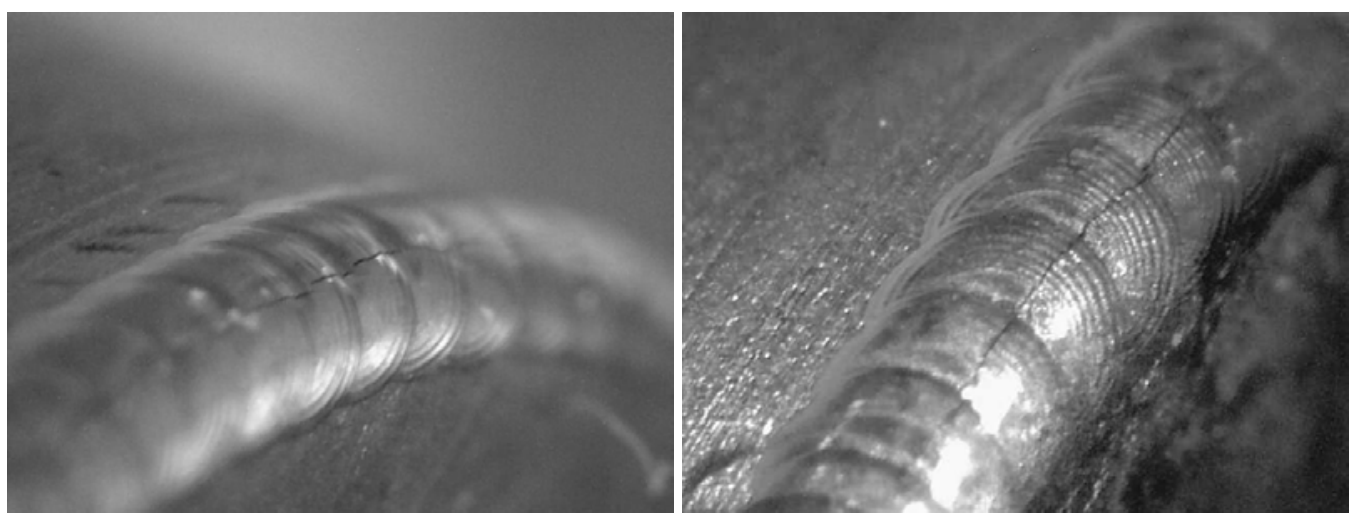

Figure 6. Detail of the welded joint tungsten tubing-tungsten disk

From Figure 6 it is obvious that a crack developed along the entire welded joint. Next changing the welding parameters the joint was welded without cracking, thus resulting in a hermetically sealed part.

Example of the welded joint tungsten tube/tungsten cap is given in Figure 7. From Figure 7 it is observed that the welded joint tungsten disk /tungsten tube is shiny and does not show any cracks. Leak testing showed no leaks either. Half dozen parts were welded using this procedure and all were good. Initial laser welding was performed by Laser Precise, Knoxville, TN and all other by Alabama Laser, Munford, Al. 


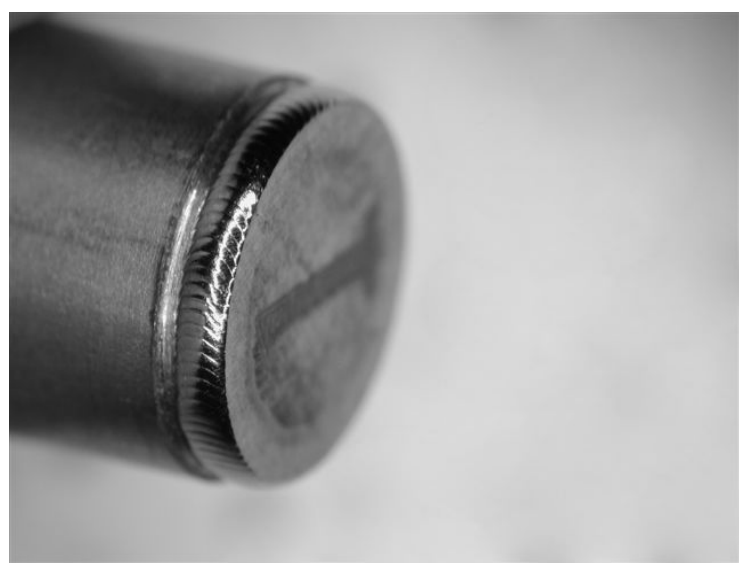

Figure 7. Welded tungsten tube joint

\subsubsection{Prototype DD cells}

The design of the prototype DD cell is identical to the dummy cell except for electrode materials.

The assembled DD cell is shown in Figure 8.

Figure 9 shows cathodic compartment.

The cell consists of an assembly (cathode compartment) comprising an alumina header glass sealed to the $\beta$ "-alumina tube, which is then sealed to an alumina plate thus closing the assembly. Tungsten filling port is located in the center of the alumina top. A metal collar is attached to the above assembly. The cathode compartment is installed in the metal case and the metal collar is welded to the case. Metal case contains sodium and serves as anode compartment. Cathode mixture is loaded into the cathode compartment through the filling port which is then welded thus sealing the cathode compartment and completing the assembly of the cell. All seals as well as assembled cells were tested on leak. 


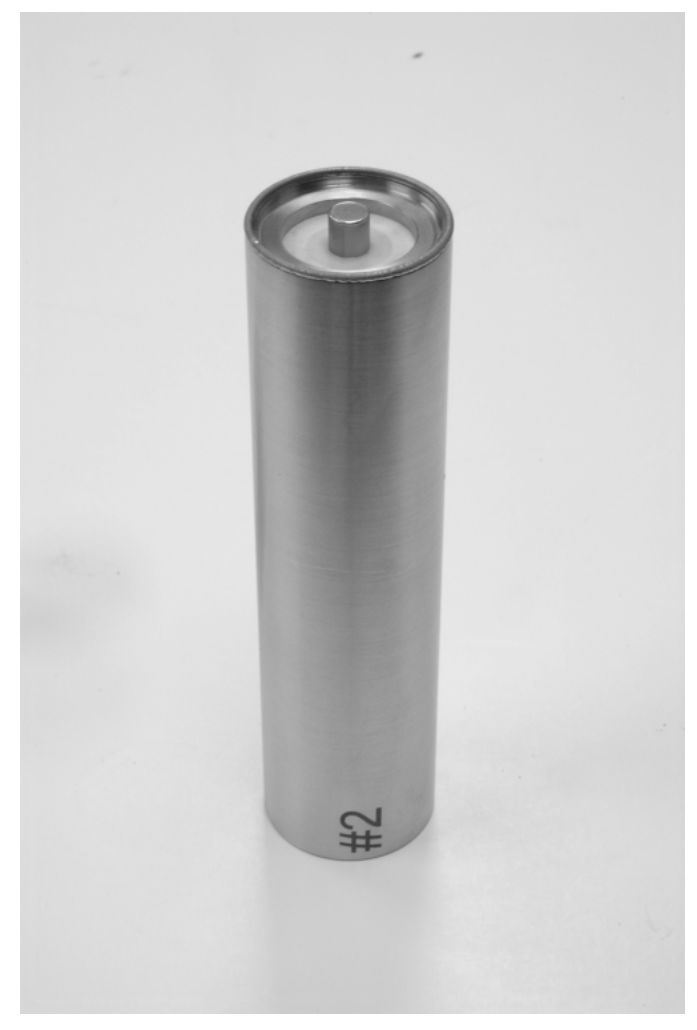

Figure 8. Assembled DD cell

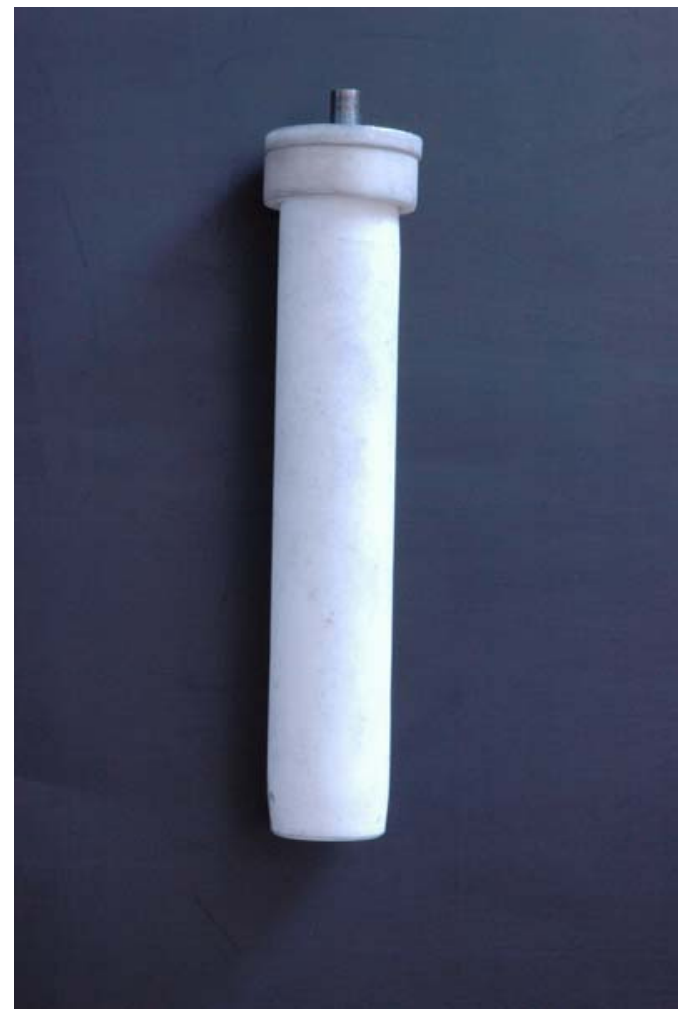

Figure 9. Cathodic compartment; beta "- alumina tube glass bonded to alumina header and alumina header bonded to alumina top. 
A special fixture was designed and built for welding the filling port of the cell.

This fixture allowed transferring the cell from the dry box to the laser welding equipment and performing the welding under inert atmosphere; thus the cell is never in contact with outside environment.

\subsubsection{Electrical performance of cells}

A number of cells each with capacity $3 \mathrm{Ah}$ were assembled and submitted to electrical performance testing.

Charge/discharge cycling at $200^{\circ} \mathrm{C}$ and constant current of $150 \mathrm{~mA}$ of first assembled cells was unsuccessful. Several cells showed a leak in the cathode compartment (leak through the weld). After charging for a short time the cell showed very high resistance. Usually, this is a sign of a possible cell leakage. With an increase in the cell resistance charging voltage also increased rapidly achieving a very high value. The testing was discontinued and cell submitted to the leak test which indicated a leak in the cathode compartment (filling port).

After that the welding fixture was modified and quality of Laser welded joints tested on two dummy cells. These cells did not contain chemicals; however, all other components were identical to the regular cell except for beta"-alumina tube which was replaced by alumina. The welded joints obtained were good and did not show any cracks or defects. A new cell was assembled and its filling port was welded. Examination of the welded joint indicated that the welding joint was good and absent of cracks and defects. 
This cell was submitted to charge/discharge cycling at $200^{\circ} \mathrm{C}$ using a constant current of $120 \mathrm{~mA}$.

Figure 10 shows discharge and charge curves for the cell.

The curves demonstrate expected behavior at the start of cycling. First cycle is discharge for a short time followed by charging. During discharge the cell resistance is low (aluminum formation), however, during subsequent charging voltage increases very fast as well as OCV. Initial cell resistance is very big then with time decreases.

Figure 11 shows continuation of charging for the same cycle. The charging voltage and the OCV both increased slowly with time. However, after $\sim 2$ hours of charging the cell begun to leak and further testing was discontinued. Careful inspection of the cell

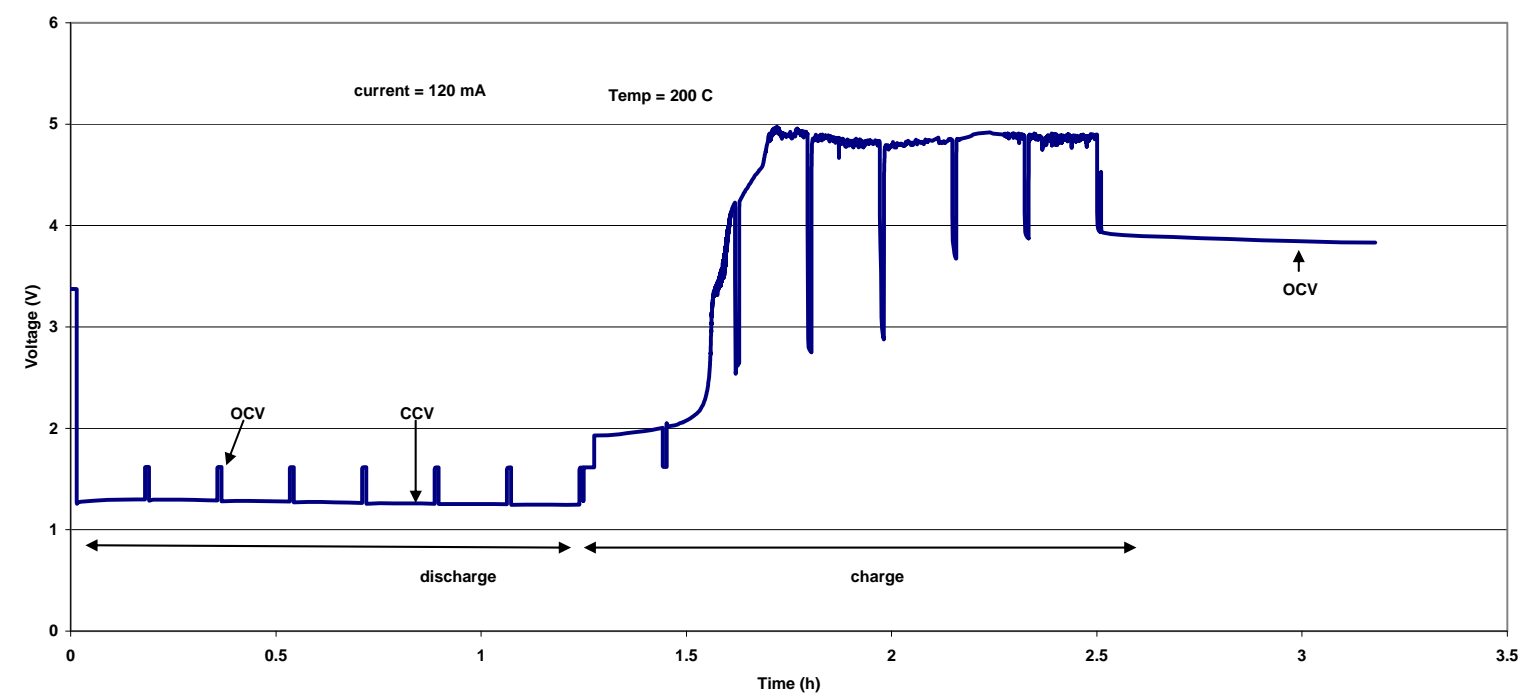

Figure 10. Discharge/charge curves for the DD cell at $200^{\circ} \mathrm{C}$ at $120 \mathrm{~mA}$.

indicated a very thin crack on the filling tubing which was covered by yellowish deposit. However, the crack did not extend to the welded joint. This seems to be a consequence of the defect in material itself. Employed tungsten tubings were made mechanically by 
drilling the tungsten rod. This method of fabrication of the tubings will introduce stresses in the material which could affect its mechanical properties producing hair thin cracks over time or under specific conditions. Using tungsten tubing made by different manufacturing methods will solve this problem, for example, tubings made by chemical methods such as EDM. The tubing made by this method does not introduce stress in the material and it will be applicable for obtaining leak tight seal with no cracks neither in the weld nor in the tubing.

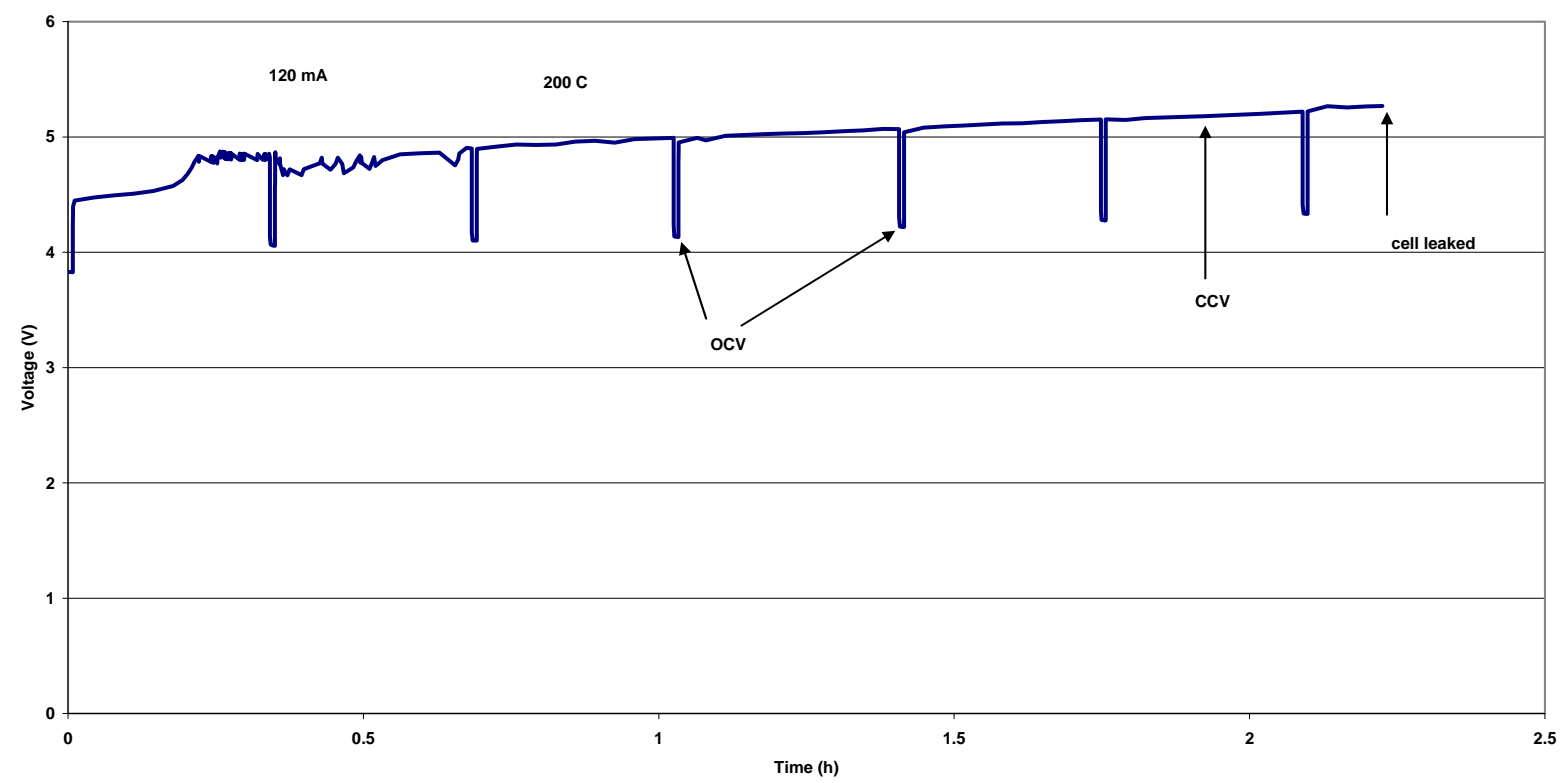

Figure 11. Charging curve for DD cell at $200^{\circ} \mathrm{C}$ and $120 \mathrm{~mA}$

\subsection{Task 3}

At this time the project had to be stopped therefore the last part of the Task 3 was not completed. It included: 1) charge/discharge performance at different temperatures, 
2) safety testing - cell overcharge, short-circuiting, reverse charge and puncture, 3) testing in the down-hole environment.

First two topics in Task 3 would be easy and can be completed relatively fast once the cells are made. It is expected that charge/discharge cycling of the cells at different temperatures would be somewhat different from the results obtained earlier with the cells employing incompatible materials. The cell resistance of the former would not increase with cycling thus cell capacity would not be affected by current at different temperatures. Safety testing results would not differ much for short-circuiting and puncture of the cell compared to the results obtained with cells made of incompatible or partially compatible materials. Short circuiting would not have permanent effect on operation of the cell.

During overcharging chlorine gas is generated and its pressure is direct function of the extent of overcharge; higher the overcharge higher the pressure of chlorine gas. High pressure of chlorine may compromise the seal causing the cell to leak or even cause breakage of the seal. This will depend on how much pressure the cathodic compartment seal can sustain. The weak point in the seal for the present cell is probably the filling port seal. Our experience based on previously tested cells (closed with a flange) showed that the overcharged cell generated chlorine pressure of $\sim 4.4 \mathrm{MPa}$ but its operation was not affected. Reverse charging will not affect the cell operation as long as it is not too long. Testing of the cells in down-hole environment certainly would be easy to perform once the cells are available. However, it was somewhat too optimistic from us to expect that the testing can be completed during this project period. To do such testing not only should a number of cells be available, but the testing tool and a well should also be 
available, which was not easy to find. What could have been accomplished is to simulate the testing under conditions similar to that in the well. 


\section{CONCLUSION}

Rechargeable cell based on the electrochemical system Na/beta"-alumina/S(IV) in molten $\mathrm{AlCl}_{3} / \mathrm{NaCl}$ was designed and built for application as a power source in oil/gas deep drilling. Cell operates in the temperature range of $150^{\circ} \mathrm{C}$ to $250^{\circ} \mathrm{C}$.

A prototype 3Ah DD size cell was designed and built with special emphasis on seal assemblies. The cell consisted of a stainless steel case containing sodium serving as anode compartment and had cathode compartment containing catholyte installed in the stainless steel case. Both compartments were closed by seal assemblies which were critical components for building the stable and long lasting cell. Therefore the main objective for this project was to develop leak tight, compatible, and thermally stable seals. Anode compartment was sealed by a thermo compression bond (TCB). Sealing assembly for the cathode compartment encompassed four seals: three glass seals and tungsten tubing/tungsten cap welded joint (filling port seal). All the seals made were leak tight except for the tungsten filling port which was a major obstacle for completion of the cell assembly on proposed time. Development of a method for successful Laser welding the tungsten filling port required much longer time than originally anticipated. Pulse welding appeared to be a solution which required determining the parameters such as power, duration and shape of the pulses. First welded cells indicated cracks in the weld due to the presence of oxygen in the gas and inadequate cooling rate. This problem was solved and the most recently assembled cell was leak tight and only begun to leak after being submitted to electrochemical performance testing (charge/discharge cycling) for some time at $200^{\circ} \mathrm{C}$. It appears that this leak is due to a crack in the tubing but not in the 
weld; this may be a consequence of a defect in material which is related to its manufacturing method. Employed tubings were made by the method which could introduce stresses in the material thus causing cracks. This problem will be solved by using material made by methods that do not introduce stresses. At this point the project had to be discontinued.

It can be concluded that during this project the high temperature Na/beta"alumina/S(IV) in molten $\mathrm{AlCl}_{3} / \mathrm{NaCl} \mathrm{DD}$ size cell was designed and built. The seals which are a major obstacle for proper operation of the DD cell were successfully built. With the incorporation of changes to the materials mentioned the cells will be ready for almost routine performance testing and safety testing. It is expected that the cells will perform as predicted. For example, the cells will show low resistance, high coulombic efficiency, no self-discharge and long cycle life. The cells should be submitted to safety testing as well. It is expected that there will not be any unexpected behavior and failures. After completing these tests the cell will be ready for commercial application and testing in down-hole environment. Mentioned testing activities should take less than six months to complete. Duration of down-hole testing will depend on type of testing, drilling tools used and environment (low temperature, high temperature). 


\section{REFERENCES}

1. "High-Pressure High-Temperature Technology Requirements", Kurkjian, Gulf Research, November, 2004.

2. "Benchmarking Deep Drilling and Completion Technologies", Rogers, Lambert and Wolhart, Gas TIPS, Spring 2004, Vol. 10, No.2.

3. J. Caja, T. D. J. Dunstan and G. Mamantov, Proceedings of the $36^{\text {th }}$ Power Sources Conference, Cherry Hill, NJ, 1994, pp. 337-340

4. G. Mamantov and J. Hvistendahl, J. Electroanal. Chem., 168, 451( 1984).

5. G. Mamantov, R. Marassi, M. Matsunaga, Y. Ogata, J. P. Wiaux, and E.J. Frazer, J. Electrochem. Soc., 127, 2319 (1980).

6. G. Mamantov, J. Caja, and T. D. J. Dunstan, Extended Abstract No. $76,182^{\text {nd }}$ (Fall) Meeting of the Electrochem. Soc., Toronto, Ontario, Canada, October 11-16, 1992. 